\title{
TEKNIK PENANGKAPAN IKAN DENGAN JARING LINGKAR (PUKAT CINCIN) DI WADUK IR. H. DJUANDA
}

\author{
Siti Mariyam ${ }^{1)}$ \\ 1) Teknisi Litkayasa pada Loka Riset Pemacuan Stok Ikan, Jatiluhur-Purwakarta \\ Teregristasi I tanggal: 5 Juli 2006; Diterima setelah perbaikan tanggal: 19 April 2007; \\ Disetujui terbit tanggal: 25 Mei 2007
}

\section{PENDULUHUAN}

Waduk Ir. H. Djuanda merupakan suatu badan air yang membendung Sungai Citarum, yang beroperasi sejak tahun 1967 dengan luas maksimal $83 \mathrm{~km} 2$ dan luas lahan $4.500 \mathrm{~km} 2$. Fungsi dari Waduk Djuanda adalah untuk pembangkit listrik, irigasi wisata, dan sumber panghasilan nelayan dengan cara menangkap ikan. Kedalaman rata-rata 36,4 m dengan kedalaman maksimum $95 \mathrm{~m}$. Berarti waduk ini tergolong perairan yang relatif luas dan cukup dalam (Tjahjo, 1986).

Jaring lingkar (pukat cincin) merupakan salah satu alat tangkap yang digunakan untuk menangkap ikan di waduk. Jaring lingkar pada umumnya berbentuk empat persegi panjang, tidak berkantong dan digunakan untuk menangkap ikan di permukaan. Penangkap ikan dengan alat jaring lingkar, dilakukan pada malam hari (antara matahari terbenam sampai dengan matahari terbit).

Menurut Ayodhyoa (1976) alat tangkap dan tehnik penangkapan ikan di Indonesia pada umumnya bersifat tradisional. Pendapat ini tidak sepenuhnya benar, karena pada saat ini sudah banyak usaha menangkap ikan yang dengan menggunakan alat bantu moderen, seperti Echosonder dan sebagainya.

\section{POKOK BAHASAN}

\section{Bahan dan Alat}

Jaring

Terbuat dari nylon dengan ukuran 2,5 dan 3,5 inch, panjang $100 \mathrm{~m}$ dan lebar $140 \mathrm{~m}$.

\section{Tali ris}

Tali ris terdiri atas ris atas, bawah, tali pelampung, dan tali pemberat yang menggunakan bahan kuralon dengan ukuran diameter $8 \mathrm{~mm}$.

\section{Tali ring}

Tali ring yang berfungsi untuk menggantung cincin terbuat dari bahan kuralon dengan diameter $8 \mathrm{~mm}$.

\section{Tali kolor}

Tali kolor terbuat dari bahan kuralon yang ukuran diameter $12 \mathrm{~mm}$ dengan panjang $100 \mathrm{~m}$.

\section{Pelampung}

Pelampung terbuat dari busa dengan ukuran diameter $5 \mathrm{~cm}$ dengan bobot $17 \mathrm{~kg}$.

\section{Cincin}

Terbuat dari tembaga dengan ukuran diameter 10 $\mathrm{cm}$ dengan bobot sekitar $400 \mathrm{~g}$.

\section{Pemberat}

Pemberat terbuat dari timah dengan ukuran panjang $3 \mathrm{~cm}$ diameter 3 sampai dengan $5 \mathrm{~cm}$.

\section{Kapal penangkapan}

Kapal yang digunakan untuk penangkapan memakai jaring lingkar (pukat cincin) di Waduk Jatiluhur perahu berukuran panjang $5 \mathrm{~m}$, lebar $80 \mathrm{~cm}$, dan tinggi $40 \mathrm{~cm}$. Mesin yang di pakai adalah mesin tempel merk Honda 5,5 pk dengan bahan bakar bensin.

\section{ASPEK PENANGKAPAN}

\section{Waktu Penangkapan}

Jaring lingkar (pukat cincin) yang dioperasikan di Waduk Jatiluhur dilakukan pada malam hari. Nelayan pada umumnya hanya mencari di mana ada gerombolan ikan. Pada umumnya setting (penurunan alat) dilakukan 1 kali selama 1 kali operasi. Namun, dalam keadaan tertentu volume panangkapan bias dikurangi atau ditambah pengoperasian alat tangkap ini dilakukan oleh 3 orang

\section{Tehnik Pengoperasian}

1. Pertama-tama harus menemukan gerombolan ikan, ada gerombolan ikan ditandai dengan ada ikan-ikan yang melompat-lompat, sehingga muncul buih-buih di permukaan air akibat udara 
yang dikeluarkan oleh ikan. Kemudian ada burungburung yang menukik-nukik dan menyambarnyambar di permukaan.

2. Setelah membaca tanda-tanda tersebut dilakukan pelingkaran jaring dengan menghadang arah renang gerombolan ikan. Pada waktu melingkari gerombolan ikan, kapal dijalankan secepat mungkin dengan tujuan agar gerombolan ikan segera terkepung.

3. Setelah ikan terkurung bagian bawah jaring ditutup dengan cara menarik tali yang dipasang sepanjang bagian bawah jaring (tali kolor) melalui cincin.

\section{Pengangkatan Alat dan Pengambilan Ikan}

1. Setelah tali kolor tertarik semua, maka sedikit demi sedikit bagian-bagian jaring dinaikan ke atas kapal.

2. Setelah sebagian jaring dinaikan ke atas kapal, ikan-ikan yang terkurung dapat dimulai diambil atau dinaikan ke atas kapal dengan menggunakan alat bantu seser.

3. Kemudian jaring dapat dinaikan ke atas kapal sambil disusun pada tempat yang telah ditentukan seperti pada waktu mau mulai operasi dengan tujuan agar jaring dapat langsung dipergunakan untuk operasi selanjutnya.

4. Dari hasil pengamatan dapat diketahui hasil tangkapan trip per hari $95 \mathrm{~kg}$, hasil tangkapan disajikan pada Tabel 1.

Tabel 1. Hasil tangkapan jaring lingkar di perairan Waduk Ir. H. Djuanda, bulan Maret 2006

\begin{tabular}{lcl}
\hline \multicolumn{1}{c}{ Jenis ikan } & Hasil tangkapn $\mathbf{( k g )}$ & \multicolumn{1}{c}{ Keterangan } \\
\hline Ikan nila (Oreochromis niloticus) & 70 & Harga penjualan untuk ikan nila \\
Ikan oskar $\quad$ (Amphilophus & 25 & $\begin{array}{l}\text { Rp.3.000,-- per kg, sedangkan untuk ikan } \\
\text { oskar Rp.1.500,- per kg }\end{array}$ \\
citrinellus) & & \multicolumn{2}{c}{} \\
\hline
\end{tabular}

\section{DAFTAR PUSTAKA}

Tjahjo, D. W. H. 1986. Ciri-ciri morphologi dan potensi pengembangan perikanan Waduk Saguling, Jatiluhur, dan Wonogiri. Buletin Penelitian Perikanan Darat. Vol.5 No.1. Hal.47-55.
Ayodhyoa, A. U. 1976. Teknik penangkapan ikan. Bagian Teknik Penangkapan Ikan. Bogor. Institut Pertanian. 
Lampiran 1. Gambar pukat cincin (purse seine)

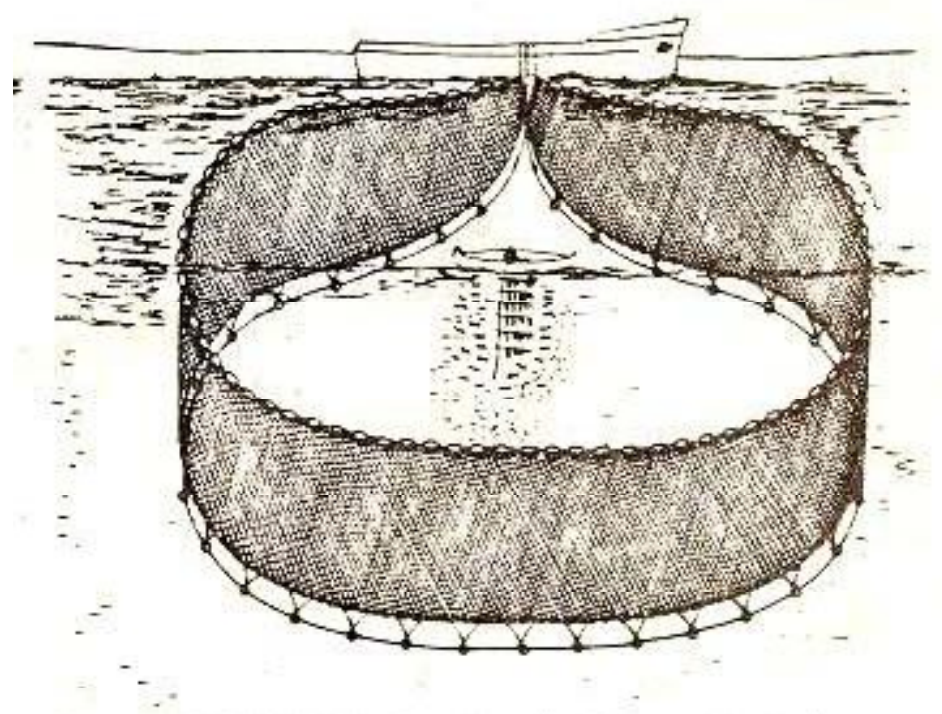

GAMBAR. Pukat Cincin (Purse Seine) 